\title{
Iron Deficiency Anemia due to Long-time Case Iron Deficiency Anemia due to Long-time Report Bloodletting Using Cupping
}

\author{
Seung-Jun Lee, Young-Sung Suh*, Yeon-Ju Lee, Dong-Gil Cho, \\ Min-Ji Lee, Dae-Hyun Kim
}

Department of Family Medicine, Keimyung University Dongsan Hospital, Keimyung University

College of Medicine, Daegu, Korea

\begin{abstract}
We report three cases of iron deficiency anemia due to long-time bloodletting using cupping. Case 1 was a 52-year-old man who sought evaluation at the Health Promotion Center in our hospital due to fatigue and dyspnea on exertion (DOE). There were no abnormal findings on his general health examination, except anemia. He has performed self-bloodletting for a long time with cupping on his back and extremities for fatigue, myalgias, or polyarthralgias. Case 2 was a 52 -yearold woman with fatigue and DOE. The physical examination revealed a systolic murmur at her left lower anterior chest and pale conjunctiva. The initial hematocrit was $22.4 \%$ and the hemoglobin was $6.4 \mathrm{~g} / \mathrm{dL}$. She has self-bloodletted using cupping 2 to 3 times a week when she felt tired or had myalgias. Case 3 was a 35-year-old man with sudden onset fatigue and DOE. He had severe DOE during a challenging physical test. He frequently received bloodletting using cuppings on his back and extremities by a doctor of Oriental medicine. There were no abnormal findings on the general health examination, except anemia. All three patients were diagnosed with iron deficiency anemia due to chronic blood loss. We recommended stopping bloodletting using cupping and prescribed oral iron supplements.
\end{abstract}

Keywords: Iron Deficiency Anemia; Bloodletting; Cupping

\section{INTRODUCTION}

According to the 3rd Korea National Health \& Nutrition Examination Survey, ${ }^{1)}$ the prevalence of anemia in Koreans $>10$ years of age is $2.2 \%$ in males and $9.5 \%$ in females. In males, anemia has an increasing tendency after the 5 th decade; the highest frequency is among those in the 8 th decade (18.9\%). In females, the peak age for anemia is the 4th decade due to childbearing (12.1\%). The prevalence of anemia is increased in the elderly in both genders.

Received: August 19, 2009, Accepted: December 31, 2010

${ }^{*}$ Corresponding Author: Young-Sung Suh

Tel: 053-250-7263, Fax: 053-250-7071

E-mail: ysseo@dsmc.or.kr

Korean Journal of Family Medicine

Copyright $@ 2011$ by The Korean Academy of Family Medicine
Therefore, anemia is a highly prevalent hematologic condition and might be a sign to occult diseases.

It is well-accepted that iron deficiency develops due to well known mechanisms, alone or in combination, i.e., inadequate intake, reduced absorption, a physiologic increase in demand, or an excessive loss of iron. ${ }^{2)}$ In the current report, we describe three cases of iron deficiency anemia due to long-time bloodletting using cupping, also known as "puhang" in Oriental Medicine.

\section{CASE REPORT}

\section{Case 1}

A 52-year-old man with a 1 month history of fatigue and dyspnea on exertion (DOE) visited the Health Promotion Center of Keimyung University Dongsan Medical Center in Daegu, Korea. Based on his personal history, he has performed self-bloodletting for a long time with cupping on his back and extremities when he 
felt fatigue, myalgias, or polyarthralgias. Other than anemia, no abnormal findings existed on his general health examination, which included a chest X-ray, electrocardiography, gastroduodenoscopy, ultrasonography of the upper abdomen, pulmonary function testing, a stool occult blood test, and blood chemistry panel with C-reactive protein. He denied any history of gastrointestinal bleeding, nasal bleeding, and abdominal surgery within 6 months, but he had a laparoscopic cholecystectomy for cholelithiasis 1 year ago. The hemogram and iron studies were as follows: hematocrit, 25.9\% (normal range, 37 to 52\%); hemoglobin, $7.9 \mathrm{~g} / \mathrm{dL}$ (normal range, 12 to $18 \mathrm{~g} / \mathrm{dL}$ ); mean corpuscular volume (MCV), $68.6 \mathrm{fl}$ (normal range, 80 to $99 \mathrm{fl}$ ); mean corpuscular hemoglobin $(\mathrm{MCH}), 20.9 \mathrm{pg} /$ cell (normal range, 27 to $31 \mathrm{pg} /$ cell); mean corpuscular hemoglobin concentration (MCHC), $30.5 \mathrm{~g} / \mathrm{dL}$ (normal range, 33 to $37 \mathrm{~g} / \mathrm{dL}$ ); serum iron, $20.3 \mu \mathrm{g} / \mathrm{dL}$ (normal range, 53 to $167 \mu \mathrm{g} / \mathrm{dL}$ ); total ironbinding capacity (TIBC), $458.1 \mu \mathrm{g} / \mathrm{dL}$ (normal range, 167 to $513 \mu \mathrm{g}$ / $\mathrm{dL}$ ); and ferritin, $4.2 \mathrm{ng} / \mathrm{mL}$ (normal range, 20 to $60 \mathrm{ng} / \mathrm{mL}$ ). The red blood cells had a hypochromic, microcytic appearance on the peripheral blood smear; there were no abnormal findings in the cell count or morphology of white blood cells and platelets. The patient was diagnosed with iron deficiency anemia due to chronic blood loss through self-bloodletting using cupping.

As soon as the cause of iron deficiency anemia was revealed, we recommended he stop bloodletting using cupping and prescribed oral iron for 6 months. Follow-up blood tests 6 months later revealed a normal hematocrit $(38.6 \%)$, hemoglobin $(12.1 \mathrm{~g} / \mathrm{dL})$, serum iron
$(62.8 \mu \mathrm{g} / \mathrm{dL})$, and TIBC $(428.7 \mu \mathrm{g} / \mathrm{dL})$, but the serum ferritin was low $(6.03 \mathrm{ng} / \mathrm{mL})$. He thought bloodletting with cupping was a method for health promotion, according to his cultural beliefs.

\section{Case 2}

A 52-year woman with fatigue and DOE sought evaluation in the Family Medicine Outpatient Clinic of Dongsan Medical Center in Daegu, Korea. The physical examination in the Outpatient Clinic revealed a systolic murmur at the left lower anterior chest and pale conjunctiva. Multiple circular patch skin lesions and subcutaneous hemorrhages because of self-bloodletting with cupping were on the shoulders and calves. The heart shadow on the chest radiograph was increased in comparison with the last examination a year ago (Figure 1). Thyroid function testing and gastroduodenoscopy revealed no abnormal findings. The initial hemogram values were as follows: hematocrit, 22.4\%; hemoglobin, 6.4 g/dL; MCV, 66 fl; MCH, 18.9 $\mathrm{pg} /$ cell; and reticulocyte count, $2.89 \%$. She has self-bloodletted using cupping 2 to 3 times a week for fatigue or myalgias, especially involving her shoulders and legs. Our diagnosis for the patient was iron deficiency anemia.

We strongly recommended not continue self-bloodletting using cupping for improvement of subjective symptoms. After a 6-month replacement of oral iron, the hemoglobin was $13.8 \mathrm{~g} / \mathrm{dL}$ and the hematocrit was $40.1 \%$. The serum iron, TIBC, and ferritin levels were $127.8 \mu \mathrm{g} / \mathrm{dL}, 314 \mu \mathrm{g} / \mathrm{dL}$, and $68.18 \mathrm{ng} / \mathrm{mL}$, respectively. Her fatigue and DOE also improved.
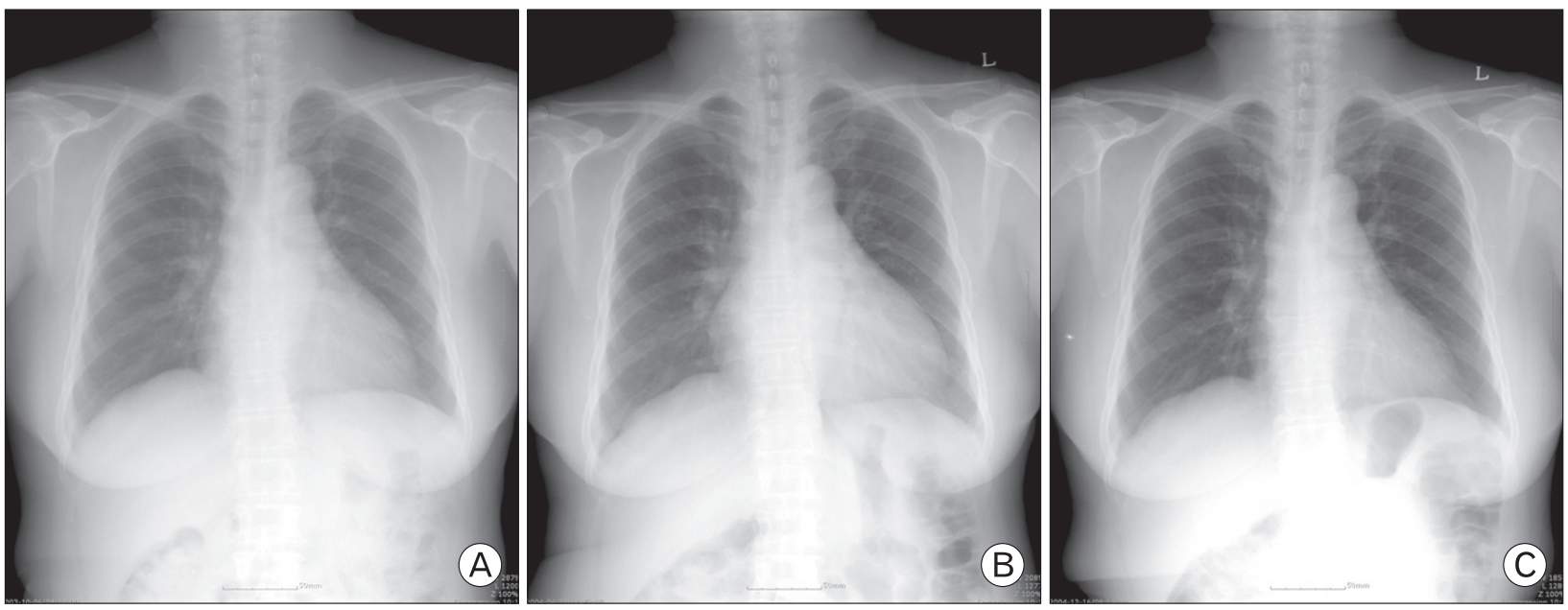

Figure 1. Chest radiography series of a 52-year-old woman. (A) Chest radiography shows a normal heart shadow 1 year ago. (B) Chest radiography showed an increased heart shadow at the time of evaluation compared to 1 year earlier. (C) Six months later, the heart shadow returned to normal. 


\section{Case 3}

A 35-year-old man sought evaluation at the Health Promotion Center of Keimyung University Dongsan Medical Center in Daegu, Korea. His chief complaint was the sudden onset of fatigue and DOE. A week ago, he had severe DOE during a challenging physical test, which included running $100 \mathrm{~m}$. This test was an employment evaluation to be a civil servant. Other than the anemia, there were no abnormal findings on the EKG, chest radiography, pulmonary function tests, stool occult blood test, gastroduodenoscopy, and blood biochemical panel on the general health examination. The initial hemogram and iron study findings were as follows: hemoglobin, $10.9 \mathrm{~g} / \mathrm{dL}$; hematocrit, 35.9\%; serum iron, $30.8 \mu \mathrm{g} / \mathrm{dL}$; TIBC, $392 \mu \mathrm{g} / \mathrm{dL}$; and ferritin, $5.21 \mathrm{ng} / \mathrm{mL}$.

Prior to visiting our hospital, he had frequently received bloodletting using cuppings on his back and extremities by a doctor of Oriental medicine for 5 months. We suggested avoiding bloodletting using cupping. After iron replacement therapy for 3 months, there was increase in hemoglobin (14.5 g/dL), hematocrit (44.9\%), serum iron $(60 \mu \mathrm{g} / \mathrm{dL})$, and ferritin $(24.1 \mathrm{ng} / \mathrm{dL})$.

\section{DISCUSSION}

Herein we describe iron deficiency anemia due to chronic bloodletting using cupping without consideration of physical conditions. Bloodletting involves direct incision of the vein with a lancet to bleed after compressing the arm above the bloodletting site. ${ }^{3)}$ In modern medicine, bloodletting is used to treat hemochromatosis as phlebotomy; ${ }^{4,5)}$ sometimes bloodletting by leaches was used to improve success with graft augmentation after graft or reconstruction surgery.

Bloodletting was practiced since the ancient Greek times $(1,000$ $\mathrm{BC})$. Following this period, bloodletting was used to treat fever and local inflammation. Around the times of Hippocrates, it was believed that there were four types of body fluids (blood, mucus, yellow bile, and black bile). It was thought that if one of the body fluids was not enough, or too much, one's health was damaged. They also believed that diseases could be treated by balancing the body fluid. Due to this belief, bloodletting was practiced. ${ }^{7-9)}$

In the 18th and 19th centuries, bloodletting (phlebotomy) was practiced to treat fever, hypertension, pneumonia, and pulmonary edema. In the 18th and 19th centuries, Hunter, the father of modern surgery, judged the prognosis of a disease by the amount of fat or blood clot component in drawn blood.' George Washington, the first President in the US, suffered from acute epiglotitis. Mozart, an 18th century composer, suffered from rheumatic fever. Both died from what turned out to be hypovolemia due to excessive bloodletting. ${ }^{3)}$

Traditional cupping, using heated cups, was practiced since the ancient times all over the Orient and Western countries. Heating the cups was the method used to obtain suction: the hot air in the cups has a low density and, as the cups cool with the opening sealed by the skin, the pressure within the cups declines, sucking the skin into it. Recently, the pressure in the cup can be declined by removal of air using a syringe on the tip of the cup. Eventually, blood congestion or ecchymoses develop.

Cupping was practiced at the meridian or local site of inflammation, where there is much less bleeding than bloodletting. In Oriental medicine, cupping was applied by an Oriental medical doctor or acupuncturist. Currently, people who want to use cupping at home in Korea can buy the devices easily.

In modern times, there are few reports about death or side effects related to bloodletting or cupping. There is a case report involving a patient who had iron deficiency anemia due to chronic bleeding caused by bloodletting. Eventually, the patient had reversible cardiac hypertrophy, and recovered after iron supplement therapy. ${ }^{10)}$

\section{요약}

사혈은 고대 그리스 시절부터 해열과 항염증 목적으로 사 용되어 왔으며 현재는 혈색소병과 같은 특수 질환에서 정맥 혈을 절개함으로써 철의 과잉을 치료하는데 이용되고 있다. 부항의 경우 한의학에서 국소부위 통증이나 염증에서 실혈을 최소화하는 치료목적으로 사용되어 왔으며 현대에서는 가정 에서도 많이 사용하고 있다. 하지만 잦은 부항치료의 경우 간 접적인 실혈로 인한 어지러움, 숨참 등의 증상을 보이는 철 결 핍성 빈혈을 일으킬 수 있다. 이에 저자들은 세 가지 사례에서 잦은 부항치료 환자에서 철 보충제를 통해 빈혈증상 개선을 보였기에 보고하는 바이다.

중심단어: 철 결핍성 빈혈; 사혈; 부항 


\section{REFERENCES}

1. Korea Centers for Disease Control and Prevention. The Third Korea National Health and Nutrition Examination Survey (KNHANES III), 2005: summary. Seoul: Korea Centers for Disease Control and Prevention; 2006.

2. Denic S, Agarwal MM. Nutritional iron deficiency: an evolutionary perspective. Nutrition 2007;23:603-14.

3. DePalma RG, Hayes VW, Zacharski LR. Bloodletting: past and present. J Am Coll Surg 2007;205:132-44.

4. Barton JC, McDonnell SM, Adams PC, Brissot P, Powell LW, Edwards CQ et al. Management of hemochromatosis. Hemochromatosis Management Working Group. Ann Intern Med 1998;129:932-9.
5. Wheeler CJ, Kowdley KV. Hereditary hemochromatosis: a review of the genetics, mechanism, diagnosis, and treatment of iron overload. Compr Ther 2006;32:10-6.

6. Adams SL. The medicinal leech. A page from the annelids of internal medicine. Ann Intern Med 1988;109:399-405.

7. Turk JL, Allen E. Bleeding and cupping. Ann R Coll Surg Engl 1983;65:128-31.

8. Kerridge IH, Lowe M. Bloodletting: the story of a therapeutic technique. Med J Aust 1995;163:631-3.

9. Ulvik RJ. Bloodletting as medical therapy for 2500 years. Tidsskr Nor Laegeforen 1999;119:2487-9.

10. Sohn IS, Jin ES, Cho JM, Kim CJ, Bae JH, Moon JY, et al. Bloodletting-induced cardiomyopathy: reversible cardiac hypertrophy in severe chronic anaemia from long-term bloodletting with cupping. Eur J Echocardiogr 2008;9:585-6. 